\title{
Semiochemicals from plants and insects on the foraging behavior of Platygastridae egg parasitoids
}

\author{
Maria Carolina Blassioli-Moraes ${ }^{(1)}$, Miguel Borges ${ }^{(1)}$, Mirian Fernandes Furtado Michereff ${ }^{(1)}$, \\ Diego Martins Magalhães ${ }^{(2)}$ and Raúl Alberto Laumann ${ }^{(1)}$
}

\begin{abstract}
(1)Embrapa Recursos Genéticos e Biotecnologia, Parque Estação Biológica, Avenida W5 Norte (Final), Caixa Postal 02372, CEP 70770-917 Brasília, DF, Brazil. E-mail: carolina.blassioli@embrapa.br, miguel.borges@embrapa.br, mirianfm@terra.com.br, raul.laumann@embrapa.br (2)Universidade de Brasília, Instituto de Ciências Biológicas, Departamento de Zoologia, Campus Universitário Darcy Ribeiro, CEP 70910-900 Brasília, DF, Brazil. E-mail: magalhaes.dmm@gmail.com
\end{abstract}

\begin{abstract}
The objective of this review was to summarize the current information about semiochemicals with potential to be applied in insect pest management in agroecosystems. One of the great challenges to Neotropical agriculture is to reduce the indiscriminate use of pesticides, which can be minimized by using semiochemicals, a tool that can be applied in the field to manage pests and their natural enemies. In addition, small lipophilic molecules from insects and from the secondary metabolism of plants play a fundamental role in the chemical communication of different species that are present in important crops.

Index terms: chemical communication, herbivore-induced plant volatiles (HIPVs), oviposition-induced plant volatiles (OIPVs), pest control, pheromone, synomone.

\section{Semioquímicos de plantas e insetos no comportamento de busca de parasitoides de ovos Platygastridae}

Resumo - O objetivo deste artigo de revisão foi reunir informações atuais sobre semioquímicos com potencial para serem aplicados no manejo de insetos-praga em agroecossistemas. Um dos grandes desafios para a agricultura Neotropical é reduzir o uso indiscriminado de pesticidas, que pode ser minimizado pelo uso de semioquímicos, uma ferramenta que pode ser aplicada no campo para o manejo de pragas e de seus inimigos naturais. Além disso, pequenas moléculas lipofílicas dos insetos e do metabolismo secundário de plantas desempenham papel fundamental na comunicação química das diferentes espécies que estão presentes em importantes culturas.

Termos para indexação: comunicação química, voláteis de planta induzidos pela herbivoria (HIPVs), voláteis de planta induzidos pela oviposição (OIPVs), controle de pragas, feromônios, sinomônios.

\section{Introduction}

Increasing plant diversity in agroecosystems reduces herbivorous populations and increases the abundance of natural enemies and, consequently, their impact on pests (Schoonhoven et al., 2005). This shows that plant biodiversity could be better explored. An alternative is intercropping or multiple cropping systems using sentinel plants that release volatiles attractive to natural enemies and repellent to herbivores, pushing them away from the target crop, as in a push-pull system (Cook et al., 2007). Another, not yet used but not novel approach, is the adoption of herbivore- and oviposition-induced plant volatiles (HIPVs and OIPVs, respectively) in crop systems. HIPVs and OIPVs are used by plants in their defense against herbivores, to attract and retain their natural enemies (Vet \& Dicke,
1992). Besides plant volatiles, semiochemicals from other sources, such as insects, are also used by natural enemies when foraging for hosts and, therefore, might also be used to manipulate their behavior (Vet \& Dicke, 1992).

Semiochemicals from plants and insects may be a valuable tool because they can be used for behavioral manipulation of parasitoids, improving their impact on pest populations in agroecosystems. Foraging behavior of parasitoids includes several sequential steps: habitat location, host location and suitability, and oviposition (Godfray, 1994). During these steps, parasitoids can use physical, biochemical, and, mainly, semiochemical cues (Vinson, 1985; Godfray, 1994). The knowledge of the different steps and of the identification of the cues used by the parasitoids in each maneuver could be 
relevant to select and obtain semiochemicals that can be used for behavior manipulation.

Egg parasitoids from the Platygastridae family have been shown to be very efficient to control herbivorous pests, especially from the Pentatomidae family (Corrêa-Ferreira, 2000). In Brazil, one of the main soybean (Glycine max L.) pests, the brown stink bug Euschistus heros (Fabricius) (Hemiptera: Pentatomidae) might be controlled by these parasitoids, which include Telenomus podisi Ashmead and Trissolcus basalis (Wollaston) (Hymenoptera: Platygastridae) (Michereff et al., 2015). The occurrence of these parasitoids together with Trissolcus teretis (Johnson), Trissolcus urichi (Crawford), and Trissolcus brochymenae (Ashmead) has been widely reported in soybean crops in the country, and T. podisi is the most abundant natural enemy of $E$. heros in soybean crops, with $>80 \%$ parasitism of host eggs (Pacheco \& Corrêa-Ferreira, 2000; Michereff et al., 2015).

Since 1950, the negative effect of insecticide application to natural enemies has been observed, and studies have shown that the reestablishment of the parasitoid population takes a long time (Pickett, 1959). Nowadays, due to the intense use of pesticides, natural enemies have a restrict action in the field (Cônsoli et al., 1998).

This review will highlight: plant defense mechanisms and their interaction with natural enemies; important studies conducted in the laboratory and the field, using arable crops, as well as HIPVs and OIPVs; host semiochemicals used to attract natural enemies and for eavesdropping by parasitoids; and the main gaps to efficiently use HIPVs on field conditions to attract natural enemies.

\section{Plant defense mechanisms against herbivores and oviposition}

Plants are equipped with several mechanisms to defend themselves against herbivores, microbial pathogens, or abiotic stress, such as hydro or mechanical damage. Plant resistance against insects can be physical, morphological, or chemical. Chemical defenses in plants are derived from the secondary metabolism and can be constitutive or induced (Chen, 2008; Heil, 2008). The constitutive defense is expressed continuously, independently of biotic or abiotic stress, and it is related to the production of different types of compounds, such as proteins, amino acids, sugar, and secondary metabolites (Schoonhoven et al., 2005; Chen, 2008; Heil, 2008). Induced defense is a plant response to damage or stress, which can result in an increase in the production of volatile organic compounds, for example (War et al., 2012; Heil, 2014).

Herbivore-induced plant volatiles are released in greater amounts than constitutive volatiles. Therefore, HIPVs are more easily detectable at long distances by parasitoids, when compared, for example, to volatiles emitted by herbivores themselves or host eggs, carrying on important information to natural enemies about the location of their hosts (Vet \& Dicke, 1992; Dicke, 1999) (Figure 1). Both types of defense can be classified as direct, when directly affecting herbivores; or as indirect, when attracting and retaining natural enemies. Direct defense can involve: the reduction of vegetal tissue nutritional quality, in which the plants reduce the supply of essential metabolites to the herbivore; and the production of compounds that minimize herbivore performance or the production of deleterious (toxic) substances to the herbivore (Chen, 2008; War et al., 2012). In indirect defense, plants can 'cry for help', attracting the natural enemies of herbivores, through the release of HIPVs or OIPVs that are used by natural enemies as cues to find their host (Kessler \& Baldwin, 2002; Heil, 2008; Hilker \& Fatouros, 2015).

Constitutive indirect plant defense chiefly involves the interaction among extrafloral nectaries, food bodies, and domatia with natural enemies. These secretions and structures are used by natural enemies, mainly ants, as food and housing (Schoonhoven et al., 2005; Heil, 2008), but also by other insects, such as ladybird beetles (Pemberton \& Vandenberg, 1993), and predatory (Cuautle \& Rico-Gray, 2003) and parasitoid wasps (Heil, 2008). Chemical and morphological plant attributes can directly influence the survival, fecundity, and foraging success of natural enemies. These traits can also have indirect effects on the quality of the herbivores that feed on these plants, which, in turn, alters the physiology, behavior, or development of their natural enemies (Cortesero et al., 2000; Chen et al., 2015).

The indirectly-induced plant defense in insect-plant relationships can be elicited by herbivory and/or oviposition injury, which induces the production of volatile organic compounds and also of extrafloral nectaries (Price, 1997; Heil, 2004, 2008; Chen, 2008; 
Moraes et al., 2008). The HIPVs and OIPVs vary depending on plant species and cultivars, and influence in different ways the foraging behavior of parasitoids, such as $T$. podisi that is attracted differently to HIPVs released by three different plant species (Dias, 2015) and soybean cultivars (Michereff et al., 2011). The HIPVs emitted by the resistant soybean cultivars Dowling and IAC 100 , in laboratory bioassays, attracted T. podisi, whereas the HIPVs emitted by the susceptible cultivar Silvânia did not (Michereff et al., 2011); a similar result was observed when these cultivars were evaluated in field conditions (Michereff et al., 2015). Therefore, the effect on the third trophic level might be taken into consideration in the development of resistant plant cultivars. These issues have been proposed since the first studies with HIPVs and natural enemies in the late 1980 's, but until now there are only few examples of the role played by genetic engineering crops on the third trophic level, and none of their commercial use (Vet \& Dicke, 1992; Schnee et al., 2006).

Plants change the blend of volatile organic compounds in response to damage, either qualitatively or quantitatively (Dicke, 1999), which depends mostly on plant traits that vary among species or genotypes, and also on the different herbivore species causing the damage (Lin et al., 2008; Rasmann \& Turlings, 2008). Furthermore, the chemical profile emitted by herbivore- or oviposition-damaged plants can be markedly different from those of undamaged and mechanically-damaged ones (Moraes et al., 2005, 2008; Michereff et al., 2011). This change can be responsible for the differential attraction of parasitoids and predators (Hoballah \& Turlings, 2001). Several works have proposed the use of the plant strategy 'cry for help' in crop systems to manage pests and natural enemies. In addition, these studies suggest that these volatile compounds could increase the effect of natural enemies on herbivores, promoting a cascading effect on the lower trophic levels, leading to a reduction in feeding damage and enhancing plant fitness. However, herbivore-induced volatiles do not always play a role in the 'cry for help' strategy and can present a negative effect on plant fitness. The predator Thanasimus dubius (Fabricius) (Coleoptera: Cleridae) feeds on bark beetle adults and eggs; however, its attraction occurs when there is no way to save the plant anymore, meaning that without tree death this predator does not have its source of food (Erbilgin \& Raffa et al., 2001).

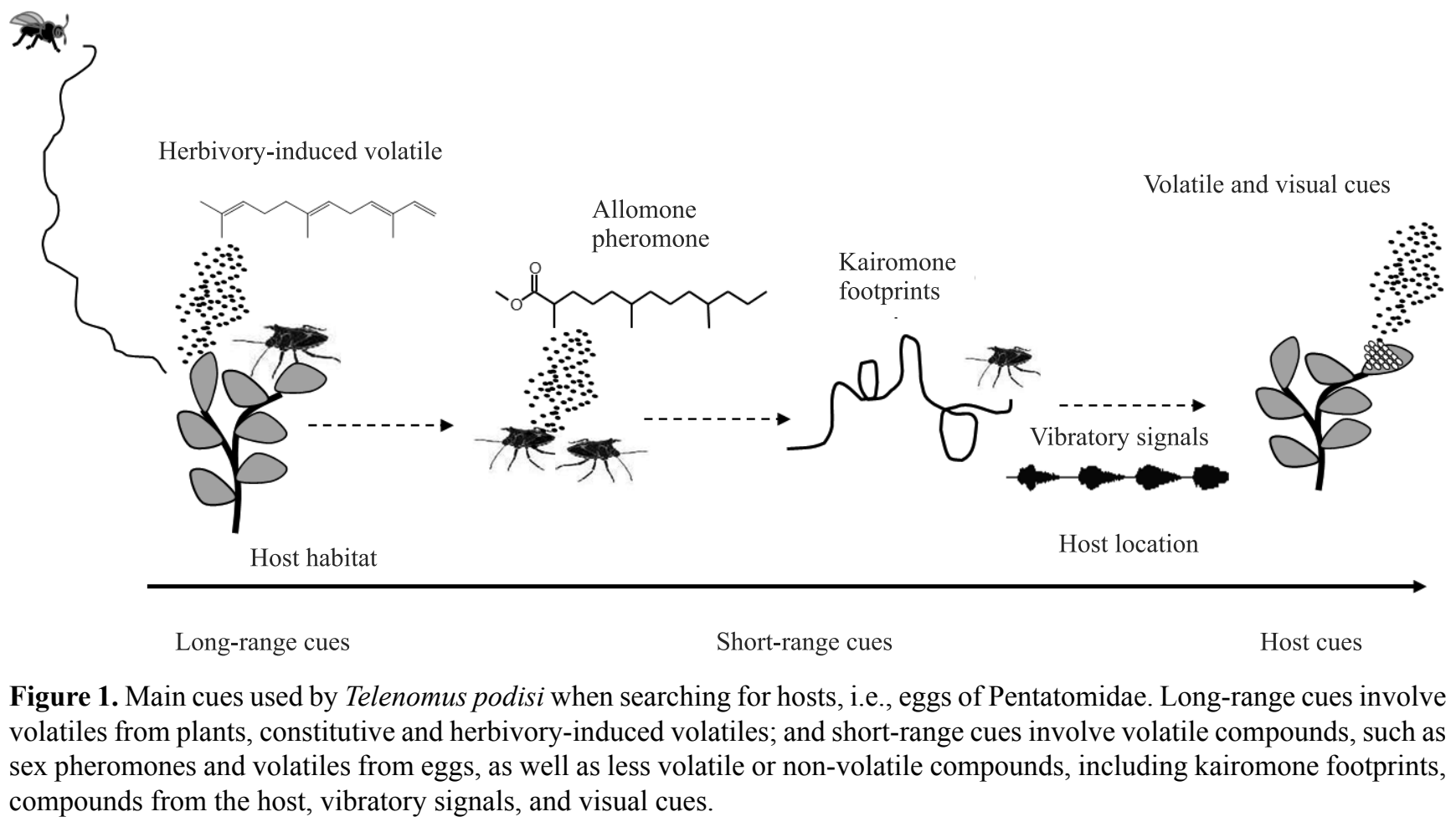

Pesq. agropec. bras., Brasília, v.51, n.5, p.454-464, maio 2016

DOI: $10.1590 / \mathrm{S} 0100-204 X 2016000500005$ 


\section{HIPVs/OIPVs and their potential to manage parasitoids in arable crops}

The HIPV and OIPV compounds from different plants are well studied and identified. These compounds, in general, are derived from the terpenoid, shikimic, and lipoxygenase pathways (Dudareva \& Pichersky, 2008). However, there are still several questions about the importance of these compounds and how they affect the attraction of natural enemies. Most of the pioneering works on HIPVs and their effects on parasitoid behavior were conducted on arable crops, such as maize (Zea mays L.), by Turlings et al. (1991) and Takabayashi et al. (1995); cotton (Gossypium hirsutum L.), by Turlings et al. (1995) and Cortesero et al. (1997); rice (Oryza sativa L.), by Lou et al. (2005) and Melo Machado et al. (2014); soybean, by Moraes et al. $(2005,2008)$ and Michereff et al. (2011, 2013); and bean (Phaseolus vulgaris L.), by Colazza et al. (2004).

Soybean plants and pigeon pea [Cajanus cajan (L.) Millsp. (Fabales: Fabaceae)] herbivored by $E$. heros release a similar volatile profile that attracts the egg parasitoid $T$. podisi. However, when soybean is feeding-damaged by Anticarsia gemmatalis Hübner (Lepidoptera: Noctuidae) larvae, the chemical profile becomes different and does not attract $T$. podisi (Moraes et al., 2005). Colazza et al. (2004) reported that $T$. basalis is attracted by synomones released by two different legume species, when the plants are damaged by herbivores and oviposition. Different soybean cultivars damaged by E. heros herbivory release a similar chemical profile between them and, in comparison to undamaged soybean plants, produce higher amounts of several compounds, such as $(E, E)-\alpha$-farnesene, methyl salicylate, $(Z)$-3-hexenyl acetate, and (E)-2-octen-1-ol (Moraes et al., 2008; Michereff et al., 2011). Olfactometer bioassays conducted with $T$. podisi and these compounds, in different mixtures and concentrations, showed that this parasitoid responds only to $(E, E)$ - $\alpha$-farnesene, as a single compound. However, when $(E, E)$ - $\alpha$-farnesene is compared to HIPVs, $T$. podisi responds preferentially to HIPVs, showing that there are other important compounds in host recognition for this parasitoid (Michereff et al., 2013). Parasitoids can also perceive HIPVs and OIPVs after landing on the host plants (Conti et al., 2010). For example, cabbage (Brassica oleracea L.) plants respond to oviposition of Murgantia histrionica (Hahn) (Hemiptera: Pentatomidae), releasing volatiles that are explored by $T$. brochymenae after they have landed on the plant (Conti et al., 2010).

The identification of HIPV or OIPV key compounds to which parasitoids are attracted to is a very complex task. Egg parasitoids are able to recognize and respond to HIPVs from different plant species that were herbivore-damaged by a common herbivore, as described by Dias (2015), who found that $T$. podisi recognized the volatiles emitted by maize, pigeon pea, and sunflower [Helianthus annuus L. (Asterales: Asteraceae)] damaged by its preferred host, E. heros; these three plants present a different chemical profile of volatiles. The described studies represent well the complexity of the interactions between plants, herbivores, and natural enemies.

This complexity is spread to other parasitoid families as well. Another example of it occurs in maize, in which studies have shown that different maize cultivars release typical blends, containing: green leaf volatiles, such as (Z)-3-hexenal, $(E)$-2-hexenal, $(Z)$-hexen-1-ol, and (Z)-3-hexen-1-yl-acetate; terpenoid compounds like linalool, $(E)$-4,8-dimethyl-1,3,7-nonatriene (DMNT), (3E,7E)-4,8,12-trimethyl-1,3,7,11-tridecatetraene (TMTT), $\quad \alpha$-bergamotene, $\quad(E, E)$ - $\alpha$-farnesene, (E)- $\beta$-farnesene, and nerolidol; and compounds from the shikimic acid pathway, including benzyl, phenethyl acetate, and indole (Gouinguené et al., 2003). When maize plants are injured by Spodoptera spp. (Lepidoptera: Noctuidae) feeding, the chemical profile changes quantitatively and attracts natural enemies, such as Cotesia marginiventris Cresson and Microplitis rufiventris Kokujev (Hymenoptera: Braconidae) (Turlings et al., 1991, 2004). When maize plants suffer herbivore damage by Spodoptera spp., the main compound released is indole, but bioassays showed that this compound apparently does not influence the response of C. marginiventris (D'Alessandro et al., 2006). However, when the minor compounds of the blend released by maize plants are removed, this parasitoid does not respond anymore (D'Alessandro et al., 2009). Recently, Erb et al. (2015) reported that the herbivore-induced indole is used as a signal of danger by other plants, inducing a priming effect on maize plants.

In this scenario, HIPVs can serve as indirect cues for egg parasitoids, providing information about 
the presence of eggs, for example, that are more inconspicuous, leading parasitoids to use these volatiles to locate plants with potential hosts (Blassioli-Moraes et al., 2011; Michereff et al., 2011; Peñaflor et al., 2011). The egg parasitoid Telenomus remus Nixon (Hymenoptera: Platygastridae) is attracted to HIPVs from maize plants damaged by Spodoptera frugiperda (J.E. Smith) (Lepidoptera: Noctuidae), after associating these volatiles with oviposition (Peñaflor et al., 2011). Soybean plants herbivore-damaged by E. heros also attract $T$. podisi, but soybean plant volatiles induced by oviposisiton do not (Moraes et al., 2008; Michereff et al., 2011). However, the combination HIPVs + OIPVs results in different profiles of chemical volatiles, attracting the parasitoid (Moraes et al., 2008; Michereff et al., 2011). Similar behavior was observed for T. basalis, in which bean plant OIPVs induced by Nezara viridula L. (Hemiptera: Pentatomidae) were not attractive to this parasitoid, but the combination HIPVs + OIPVs was (Colaza et al., 2004), suggesting that herbivore damage and oviposition appear to act synergistically.

Studies with other parasitoid families have shown that the laid egg can also induce indirect plant defense, releasing chemical volatiles that attract egg parasitoids in the laboratory and in the field (Hilker \& Meiners, 2006, 2010). The possibility of using these OIPVs was shown in a non-arable crop, the European field elm Ulmus minor Mill. (Rosales: Ulmaceae). When $U$. minor is damaged by the eggs laid by the beetle Xanthogaleruca luteola Müler (Coleoptera: Chrysomelidae), it releases a blend of OIPVs that attracts the specialistegg parasitoid Oomyzus gallerucae Fonscolombe (Hymenoptera: Eulophidae). This study showed that the homoterpene DMNT is an important component in the attraction of this egg parasitoid. In field tests, plants with DMNT-baited traps attracted more $O$. gallerucae than plants with unbaited ones (Büchel et al., 2011). It should be highlighted that there are no studies showing the attraction of Platygastridae parasitoids to OIPVs without the association of other volatiles. However, in a study to evaluate the influence of volatiles released by egg extracts of the stink bug $E$. heros and of soybean plants treated with them on the foraging behavior of $T$. podisi, this parasitoid was attracted to: volatiles emitted by one egg cluster compared to air; the acetonic extract of one egg cluster compared to acetone; and the acetonic extract of one egg cluster compared to the acetonic extract of 100 egg clusters. These results suggest that one egg cluster and its acetonic extract have volatile compounds that change $T$. podisi foraging behavior, and that the amounts and surroundings of these compounds are important for their recognition by this parasitoid.

\section{Semiochemicals from host or host-associated to manage parasitoids}

For plant volatiles, there is a large amount of information about chemicals from host or host-associated cues that parasitoids exploit when foraging. These cues can include: sex, alarm, or other pheromones; host-derivative products, as feces/ frass, debris, scale, honeydew, or host footprints; or habitat or microhabitat components (Godfray, 1994; Fatouros et al., 2008; Colazza et al., 2010). According to Aldrich (1985), an egg parasitoid can use chemical information produced by stink bugs to locate females and, indirectly, stink bug eggs.

Differently from HIPVs and OIPVs, host or host-associated cues are used by parasitoids during different steps of host searching and selection behavior, as in habitat location, host location, or host selection (Godfray, 1994; Fatouros et al., 2008). Furthermore, cues associated to host location and host selection present a more diverse nature than cues used for habitat location, and could stimulate other behaviors than taxis or kinesis locomotor responses, which are typically recorded when parasitoids are stimulated with HIPVs and OIPVs (Laumann et al., 2011; Michereff et al., 2011, 2013).

In general, information from plants, such as herbivore- or oviposition-induced volatiles, is used as long-range cues to locate the host (Kessler \& Baldwin, 2002; Moraes et al., 2005, 2008). For short-range cues, when close to the host, parasitoids may use defensive compounds, sex pheromones, and cuticular hydrocarbons (Borges et al., 1998, 2003; Laumann et al., 2009). When parasitoids are close to the host or have physical contact with it, semi- or non-volatile compounds, such as footprints and egg composition, become important for host final recognition, as well as other physical or visual factors, such as texture, color, and vibratory information (Borges et al., 2003; Aquino et al., 2012) (Figure 1). 
Telenomus podisi is an egg parasitoid of pentatomid bugs that prefers egg masses of the Neotropical brown stink bug, E. heros, whereas T. basalis shows preference for egg masses of the Southern green stink bug, N. viridula (Corrêa-Ferreira, 2000; Sujii et al., 2002). Despite this preference, Tognon et al. (2014), while studying the influence of original hosts on the chemotaxic behavior and parasitism of $T$. podisi, observed that when Tibraca limbativentris Stål (Hemiptera: Pentatomidae) was the original host, the females parasitized this species over E. heros, whereas those emerging from $E$. heros exclusively parasitized $E$. heros' eggs, suggesting that the original host can exert influence on their choice. It is important to note that the parasitoid's host searching begins with an innate behavior; however, this can be modified by successive exposure to a particular host, which can result in learning behavior during the development of the immature stage, remaining as an olfactory memory in the adult stage (Vet \& Dicke, 1992; Tognon et al., 2013).

Studies have shown that the parasitoid species $T$. podisi and $T$. basalis, besides HIPVs, use semiochemicals from stink bugs and also from their egg masses. Several arena bioassays have been carried out using single and/or simultaneous stimuli, such as egg masses; live virgin $E$. heros males and females; volatile extracts of sexually mature $E$. heros males and females; 2,6,10-methyl-trimethyltridecanoate, a component of the E. heros sex pheromone; (E)-2-hexenal, a component of the $E$. heros metathoracic gland; and hexane or air as a control. In these assays, $T$. podisi females responded to the E. heros male extracts, to 2,6,10-methyl-trimethyltridecanoate, and to (E)-2-hexenal, showing that they use chemical cues from E. heros to find their host egg masses (Borges \& Aldrich, 1992; Silva et al., 2006). Trissolcus basalis responds positively to 4-oxo-(E)-2-hexenal and (E)-2-decenal, two major components present in $N$. viridula glandular secretion, whereas $T$. podisi is attracted to crude gland extracts of the preferred host, E. heros, and has its walking pattern altered when stimulated with 4-oxo-(E)-2-hexenal (Silva et al., 2006). Besides that, $T$. podisi also responds positively to two major components of E. heros glands: (E)-2-hexenal and tridecane. These results indicate some degree of specialization in the response of two generalist parasitoid species towards defensive secretions of stink bugs (Laumann et al.,
2009). Telenomus calvus (Ashmead) uses pheromones produced by male Podisus maculiventris and Podisus neglectus (Westwood) (Hemiptera: Pentatomidae) as an indirect mechanism to locate Podisus eggs (Aldrich, 1995). This parasitoid requires eggs less than 12 hours old to successfully develop, and so it needs a reliable method of locating fresh eggs. All pheromone blends of male Podisus sp. contain (E)-2-hexenal, benzyl alcohol, and $\alpha$-terpineol, providing a reliable cue for the wasp.

At short-range foraging behavior, $T$. podisi recognizes volatile footprints from $E$. heros males (Borges et al., 2003; Silva et al., 2006). Two different strains of $T$. podisi, one from Brazil and the other from the USA, show different foraging behavior when stimulated by E. heros footprints. The Brazilian strain recognizes $E$. heros footprints, whereas the North American one does not show the same behavior and ignores the footprints of $E$. heros females, despite the fact that these parasitoids were reared from E. heros eggs (Borges et al., 2003). The obtained results indicate a high degree of specialization of natural enemies to recognize the adequate host. The North American strain used as host mainly eggs from $N$. viridula and from other North American species of the genus Euschistus (Borges et al., 2003). The same was observed for $T$. basalis, which could differentiate footprints from females and males of its host $N$. viridula (Colazza et al., 2007). The chemical footprints of $N$. viridula left on leaves change the foraging behavior of T. basalis; and the chemical footprints induce arrestment behavior on this egg parasitoid (Colazza et al., 2009). In another study, Salerno et al. (2009) showed that T. brochymenae prefers the traces left by mated females of $M$. histrionica, when compared to traces from virgin females, males, or parous host females.

In a multisensory condition, $T$. podisi uses olfactory signals to find its host at long distance. This corroborates previous studies that showed that host location is oriented primarily by olfactory cues released directly from the nontarget host egg, which is more detectable and reliable (Vet \& Dicke, 1992; Borges et al., 1998). However, in this case, visual information from the substrate could be relevant (Aquino et al., 2012). Once on the plant, the parasitoid probably passes through different steps of searching behavior. The initial searching behavior could be random or may show directionality mediated by the stink bug's vibratory signals, visual cues, or even chemicals with low 
volatility, such as cuticular hydrocarbon or volatiles from egg masses and footprints (Borges et al., 2003; Conti et al., 2010; Laumann et al., 2011; Tognon et al., 2014), followed by the final recognition of the host through chemical and physical contact traits, including visual cues (Figure 1).

\section{The potential to apply semiochemicals in arable crops to attract parasitoids}

Semiochemicals can be applied directly on plants, as spray, inducing the production of defensive chemical volatiles, which attract parasitoids, or by using a slow release dispenser, which releases the semiochemical, attracting directly natural enemies (Simpson et al., 2011; Vieira et al., 2013). The use of semiochemicals as a strategy to improve biological control has potential to work by itself, but, if combined with other strategies, its success could probably be enhanced. In general, parasitoids follow chemical cues to find their host, but if they do not find the host or a reward, i.e., food or any factor that retains them in the area, they can associate this chemical cue to the absence of host or food, and, by learning this new information, change their response by ignoring this cue (Vet \& Dicke, 1992; Blassioli-Moraes et al., 2013). Therefore, semiochemicals could be applied together with habitat manipulation, using a diversity of plants containing nectar or using push-pull systems, combining different stimuli to manipulate natural enemies and pest behavior (Cook et al., 2007; Simpson et al., 2011).

In Brazil, there are few examples of field experiments using semiochemicals to attract and retain parasitoids in field conditions. Two compounds have been evaluated in soybean fields using different approaches: (E)-2-hexenal, with slow release dispensers (rubber septa) distributed randomly on the plots (Vieira et al., 2014); and cis-jasmone, a natural phytohormone that induces the indirect defense of soybean plants (Moraes et al., 2009), sprayed directly on soybean plots, inducing them to produce volatiles (Vieira et al., 2013). Both strategies attracted Platygastridae egg parasitoids. According to Vieira et al. (2013), the richness of parasitoids was higher in soybean areas with greater plant diversity than in soybean areas only with Crotalaria juncea L. (Fabales: Fabaceae) matrix plots.

The number of studies conducted in field conditions using semiochemicals increased in the last few years, but information is still scarce (Blassioli-Moraes et al.,
2013). This is mainly due to the difficulties in knowing which compound is attractive to parasitoids in laboratory bioassays. Besides this, there are several other questions that need to be answered before field tests are placed: what amount of compounds should be used? how should they be applied? and what is the release rate necessary to attract these parasitoids? (Simpson et al., 2011; Blassioli-Moraes et al., 2013; Colazza et al., 2013). Considering these issues, one alternative is to manipulate the plants to produce and release specific volatiles, which can be done by classical breeding or genetic engineering (Schnee et al., 2006; Kunert et al., 2010; Michereff et al., 2011; Bruce et al., 2015). There is no example in the literature on this subject for transgenic transformed arable crops. However, maize transformed with a $(E)-\beta$-caryophyllene synthase gene from oregano (Origanum vulgare L.), resulting in constitutive emissions of this sesquiterpene, attracts more entomopathogenic nematodes, minimizing the damage provoked by Diabrotica spp. (Coleoptera: Chrysomelidae) root larvae (Degenhardt et al., 2009). One of the major questions concerning the continuous release of volatiles by modified plants, which, in a natural context, would only occur when the plants are disturbed, is if this difference on release timing will have the same effect on natural enemies (Kunert et al., 2010). An alternative to this problem is to identify genes that prime the chemical defense of the plants.

An easy way to manipulate natural enemies in the field is to detect cultivars and plants that can naturally attract natural enemies and keep off herbivores. Recently, Michereff et al. (2015) showed that three different soybean cultivars - two resistant (Dowling and IAC 100) and one susceptible (Silvânia) - attracted differently the egg parasitoids T. podisi and T. basalis, from the Platygastridae family, in field conditions. The authors suggest that volatiles released by the Dowling cultivar, which attracted more parasitoids, might be involved in this differential attraction.

Parasitoids can be highly specialized in relation to the chemical cues used for host searching. Moreover, in several plant-herbivore-parasitoid systems, this specificity could be related to plant genotypes, plant physiology, phenological stages, host developmental stage, among others (Turlings et al., 1995; Moraes et al., 2005). This suggests that the use of semiochemicals for parasitoid management needs to be studied 
case-by-case, and adaptations should be introduced in each particular situation.

\section{Concluding remarks}

These and other studies show that the interaction plant-natural enemies mediated by HIPVs and OIPVs has a decisive role on parasitoid host-searching behavior, and that plant biology, genetic and phenotypic characteristics also have a determinant role on community dynamics and biodiversity, with evolutionary consequences for both plant and natural enemies (Hare, 2011).

To summarize, plants have developed sophisticated defense strategies against biotic stressors (pests) using a variety of inducible defense mechanisms that can be exploited in crop protection. Besides their effect against herbivores and their attraction of natural enemies, the small lipophilic molecules released by plants also affect neighboring plants, which can respond to stress signaling by elicitation or augmentation (priming) of the defense response (Kim \& Felton, 2013; Erb et al., 2015). The ability to elicit or prime crop plants for defense upon detection of plant stress signaling provides an opportunity to develop new mixed cropping systems, and the identified stress signals associated with pest damage in the sentinel (guard crops) can be used for the activation of defense responses in the main crop.

Therefore, plant volatiles can be used in the field with different approaches: to apply synthetic plant semiochemicals to induce plant defense or attract natural enemies; in intercropping or multiple cropping systems, using plants that release volatiles that attract natural enemies and repel herbivores, pushing away the pests from the target crop; and to provide trap crops that are cultivated around the target crop to attract the pests.

Although there is a considerable amount of studies on the use of semiochemicals by natural enemies, the knowledge of how these semiochemicals can be applied in field conditions to favor the action of these parasitoids is still limited. Research on the learning ability of Platygastridae parasitoids and on how they recognize odor blends will provide information about the right doses and the right time for the application of semiochemicals, greatly helping in their correct application in the field.

\section{Acknowledgments}

To Coordenação de Aperfeiçoamento de Pessoal de Nível Superior (Capes, grant No. 99999.014964/201309), to Conselho Nacional de Desenvolvimento Científico e Tecnológico (CNPq), to Fundação de Apoio à Pesquisa do Distrito Federal (FAP-DF), and to Embrapa, for financial support; and to Universidade de Brasília (UnB), Postgraduate Program on Zoology, for permission of use of their facility.

\section{References}

ALDRICH, J.R. Chemical communication in the true bugs and parasitoid exploitation. In: CARDÉ, R.T.; BELL, W.J. (Ed.). Chemical ecology of insects 2. New York: Chapman \& Hall, 1995. p.318-363.

ALDRICH, J.R. Pheromone of a true bug (Hemiptera-Heteroptera): attractant for the predator, Podisus maculiventris, and kairomonal effects. In: ACREE, T.E.; SODERLUND, D.M. (Ed.). Semiochemistry: flavors and pheromones. Berlin: de Gruyter, 1985. p.95-119.

AQUINO, M.F.S. de; DIAS, A.M.; BORGES, M.; MORAES, M.C.B.; LAUMANN, R.A. Influence of visual cues on hostsearching and learning behaviour of the egg parasitoids Telenomus podisi and Trissolcus basalis. Entomologia Experimentalis et Applicata, v.145, p.162-174, 2012. DOI: 10.1111/j.1570-7458.20 12.01325.x.

BLASSIOLI-MORAES, M.C.; BORGES, M.; LAUMANN, R.A. The application of chemical cues in arthropod pest management for arable crops. In: WAJNBERG, E.; COLAZZA, S. (Ed.). Chemical ecology of insect parasitoids. Chichester: Wiley-Blackwell, 2013. p.225-244.

BLASSIOLI-MORAES, M.C.B.; LAUMANN, R.A.; AQUINO, M.F.S.; PAULA, D.P.; BORGES, M. Effect of Bt genetic engineering on indirect defense in cotton via tritrophic interaction. Transgenic Research, v.20, p.99-107, 2011. DOI: 10.1007/ s11248-010-9399-0.

BORGES, M.; ALDRICH, J.R. Instar-specific defensive secretions of stink bugs (Heteroptera: Pentatomidae). Experientia, v.48, p.893-896, 1992. DOI: 10.1007/BF02118429.

BORGES, M.; COLAZZA, S.; RAMIREZ-LUCAS, P.; CHAUHAN, K.R.; ALDRICH, J.R.; MORAES, M.C.B. Kairomonal effect of walking traces from Euschistus heros (Heteroptera: Pentatomidae) on two strains of Telenomus podisi (Hymenoptera: Scelionidae). Physiological Entomology, v.28, p.349-355, 2003. DOI: 10.1111/j.1365-3032.2003.00350.x.

BORGES, M.; MORI, K.; COSTA, M.L.M.; SUJII, E.R. Behavioural evidence of methyl-2,6,10-trimethyltridecanoate as a sex pheromone of Euschistus heros (Heteroptera: Pentatomidae). Journal of Applied Entomology, v.122, p.335-338, 1998. DOI: 10.1111/j.1439-0418.1998.tb01508.x. 
BRUCE, T.J.A.; ARADOTTIR, G.I.; SMART, L.E.; MARTIN, J.L.; CAULFIELD, J.C.; DOHERTY, A.; SPARKS, C.A.; WOODCOCK, C.M.; BIRKETT, M.A.; NAPIER, J.A.; JONES, H.D.; PICKETT, J.A. The first crop plant genetically engineered to release an insect pheromone for defence. Scientific Reports, v.5, p.1-9, 2015. DOI: 10.1038/srep11183.

BÜCHEL, K.; MALSKIES, S.; MAYER, M.; FENNING, T.M.; GERSHENZON, J.; HILKER, M.; MEINERS, T. How plants give early herbivore alert: volatile terpenoids attract parasitoids to egg-infested elms. Basic and Applied Ecology, v.12, p.403-412, 2011. DOI: 10.1016/j.baae.2011.06.002.

CHEN, M.S. Inducible direct plant defense against insect herbivores: a review. Insect Science, v.15, p.101-114, 2008. DOI: 10.1111/j.1744-7917.2008.00190.x.

CHEN, Y.H; GOLS, R.; STRATTON, C.A.; BREVIK, K.A.; BENREY, B. Complex tritrophic interactions in response to crop domestication: predictions from the wild. Entomologia Experimentalis et Applicata, v.157, p.40-59, 2015. DOI: 10.1111/ eea. 12344

COLAZZA, S.; AQUILA, G.; DE PASQUALE, C.; PERI, E.; MILLAR, J.G. The egg parasitoid Trissolcus basalis uses n-nonadecane, a cuticular hydrocarbon from its stink bug host Nezara viridula, to discriminate between female and male hosts. Journal of Chemical Ecology, v.33, p.1405-1420, 2007. DOI: 10.1007/s10886-007-9300-7.

COLAZZA, S.; FUCARINO, A.; PERI, E.; SALERNO, G.; CONTI, E.; BIN, F. Insect oviposition induces volatile emission in herbaceous plants that attracts egg parasitoids. Journal of Experimental Biology, v.207, p.47-53, 2004. DOI: 10.1242/ jeb.00732.

COLAZZA, S.; LO BUE, M.; LO GIUDICE, D.; PERI, E. The response of Trissolcus basalis to footprint contact kairomones from Nezara viridula females is mediated by leaf epicuticular waxes. Naturwissenschaften, v.96, p.975-981, 2009. DOI: 10.1007/ s00114-009-0548-3.

COLAZZA, S.; PERI, E.; CUSUMANO, A. Application of chemical cues in arthropod pest management for orchards and vineyards. In: WAJNBERG, E.; COLAZZA, S. (Ed.). Chemical ecology of insect parasitoids. Chichester: Wiley-Blackwell, 2013. p.246-265. DOI: 10.1002/9781118409589.ch11.

COLAZZA, S.; PERI, E.; SALERNO, G.; CONTI, E. Host searching by egg parasitoids: exploitation of host chemical cues. In: CÔNSOLI, F.L.; PARRA, J.R.P.; ZUCCHI, R.A. (Ed.). Egg parasitoids in agroecosystems with emphasis on Trichogramma. Dordrecht: Springer, 2010. p.97-148. (Progress in biological control, 9).

CÔNSOLI, F.L.; PARRA, J.R.P.; HASSAN, S.A. Side-effects of insecticides used in tomato fields on the egg parasitoid Trichogramma pretiosum Riley (Hym., Trichogrammatidae), a natural enemy of Tuta absoluta (Meyrick) (Lep., Gelechiidae). Journal of Applied Entomology, v.122, p.43-47, 1998. DOI: 10.1111/j.1439-0418.1998.tb01459.x.

CONTI, E.; SALERNO, G.; LEOMBRUNI, B.; FRATI, F.; BIN, F. Short-range allelochemicals from a plant-herbivore association: a singular case of oviposition-induced synomone for an egg parasitoid. Journal of Experimental Biology, v.213, p.3911-3919, 2010. DOI: $10.1242 /$ jeb.045922.

COOK, S.M.; KHAN, Z.R.; PICKETT, J.A. The use of push-pull strategies in integrated pest management. Annual Review of Entomology, v.52, p.375-400, 2007. DOI: 10.1146/annurev. ento.52.110405.091407.

CORREA-FERREIRA, B.S. Trissolcus basalis para o controle de percevejos da soja. In: PARRA, J.R.P.; BOTELHO, P.S.M.; CORRÊA-FERREIRA, B.S.; BENTO, J.M.S. (Ed.). Controle biológico no Brasil: parasitóides e predadores. São Paulo: Manole, 2000, p.449-476.

CORTESERO, A.M.; MORAES, C.M. de; STAPEL, J.O.; TUMLINSON, J.H.; LEWIS, W.J. Comparisons and contrasts in host-foraging strategies of two larval parasitoids with different degrees of host specificity. Journal of Chemical Ecology, v.23, p.1589-1606, 1997. DOI: 10.1023/B:JOEC.0000006424.41365.0d.

CORTESERO, A.M.; STAPEL, J.O.; LEWIS, W.J. Understanding and manipulating plant attributes to enhance biological control. Biological Control, v.17, p.35-49, 2000. DOI: 10.1006/ bcon.1999.0777.

CUAUTLE, M.; RICO-GRAY, V. The effect of wasps and ants on the reproductive success of the extrafloral nectaried plant Turnera ulmifolia (Turneraceae). Functional Ecology, v.17, p.417-423, 2003. DOI: 10.1046/j.1365-2435.2003.00732.x.

D'ALESSANDRO, M.; BRUNNER, V.; MÉREY, G. von; TURLINGS, T.C.J. Strong attraction of the parasitoid Cotesia marginiventris towards minor volatile compounds of maize. Journal of Chemical Ecology, v.35, p.999-1008, 2009. DOI: 10.1007/s10886-009-9692-7.

D’ALESSANDRO, M.; HELD, M.; TRIPONEZ, Y.; TURLINGS, T.C.J. The role of indole and other shikimic acid derived maize volatiles in the attraction of two parasitic wasps. Journal of Chemical Ecology, v.32, p.2733-2748, 2006. DOI: 10.1007/ s10886-006-9196-7.

DEGENHARDT, J.; HILTPOLD, I.; KÖLLNER, T.G.; FREY, M.; GIERL, A.; GERSHENZON, J.; HIBBARD, B.E.; ELLERSIECK, M.R.; TURLINGS T.C.J. Restoring a maize root signal that attracts insect-killing nematodes to control a major pest. Proceedings of the National Academy of Sciences of United States of America, v.106, p.13213-13218, 2009. DOI: 10.1073/pnas.0906365106.

DIAS, A.M. Resposta olfativa de Telenomus podisi (Hymenoptera: Platygastridae) para voláteis de plantas induzidos por herbivoria e oviposição de Euschistus heros (Hemiptera: Pentatomidae). 2015. 98p. Dissertação (Mestrado) Universidade Federal de Lavras, Lavras.

DICKE, M. Are herbivore-induced plant volatiles reliable indicators of herbivore identity to foraging carnivorous arthropods? Entomologia Experimetalis et Applicata, v.91, p.131-142, 1999. DOI: 10.1046/j.1570-7458.1999.00475.x.

DUDAREVA, N.; PICHERSKY, E. Metabolic engineering of plant volatiles. Current Opinion in Biotechnology, v.19, p.181-189, 2008. DOI: 10.1016/j.copbio.2008.02.011.

ERB, M.; VEYART, N.; ROBERT, C.A.M.; XU, H.; FREY, M.; TON, J.; TURLINGS, T.C.J. Indole is an essential herbivore-induced 
volatile priming signal in maize. Nature Communications, v.6, p.1-10, 2015. DOI: 10.1038/ncomms7273.

ERBILGIN, N.; RAFFA, K.F. Modulation of predator attraction to pheromones of two prey species by stereochemistry of plant volatiles. Oecologia, v.127, p.444-453, 2001. DOI: 10.1007/ s004420000606.

FATOUROS, N.E.; DICKE, M.; MUMM, R.; MEINERS, T.; HILKER, M. Foraging behavior of egg parasitoids exploiting chemical information. Behavioral Ecology, v.19, p.677-689, 2008. DOI: 10.1093/beheco/arn011.

HOBALLAH, M.E.F.; TURLINGS, T.C.J. Experimental evidence that plants under caterpillar attack may benefit from attracting parasitoids. Evolutionary Ecology Research, v.3, p.553-565, 2001.

GODFRAY, H.C.J. Parasitoids: behavioural and evolutionary ecology. Princeton: Princeton University Press, 1994. 473p.

GOUINGUENÉ, S.; ALBORN, H.; TURLINGS, T.C.J. Induction of volatile emissions in maize by different larval instars of Spodoptera littoralis. Journal of Chemical Ecology, v.29, p.145-162, 2003. DOI: 10.1023/A:1021984715420.

HARE, J.D. Ecological role of volatiles produced by plants in response to damage by herbivorous insects. Annual Review of Entomology, v.56, p.161-180, 2011. DOI: 10.1146/ annurev-ento-120709-144753.

HEIL, M. Herbivore-induced plant volatiles: targets, perception and unanswered questions. New Phytologist, v.204, p.297-306, 2014. DOI: 10.1111/nph.12977.

HEIL, M. Indirect defence via tritrophic interactions. New Phytologist, v.178, p.41-61, 2008. DOI: 10.1111/j.1469-8137.20 07.02330.x.

HEIL, M. Induction of two indirect defences benefits Lima bean (Phaseolus lunatus, Fabaceae) in nature. Journal of Ecology, v.92, p.527-536, 2004. DOI: 10.1111/j.0022-0477.2004.00890.x.

HILKER, M.; FATOUROS, N.E. Plant responses to insect egg deposition. Annual Review of Entomology, v.60, p.493-515, 2015. DOI: 10.1146/annurev-ento-010814-020620.

HILKER, M.; MEINERS, T. Early herbivore alert: insect eggs induce plant defence. Journal of Chemical Ecology, v.32, p.1379-1397, 2006. DOI: 10.1007/s10886-006-9057-4.

HILKER, M.; MEINERS, T. How do plants "notice" attack by herbivorous arthropods? Biological Reviews, v.85, p.267-280, 2010. DOI: 10.1111/j.1469-185X.2009.00100.x.

KESSLER, A.; BALDWIN, I.T. Plant-mediated tritrophic interactions and biological pest control. AgBiotechNet, v.4, p.1-7, 2002.

KIM, J.; FELTON, G.W. Priming of antiherbivore defensive responses in plants. Insect Science, v.20, p.273-285, 2013. DOI: 10.1111/j.1744-7917.2012.01584.x.

KUNERT, G.; REINHOLD, C.; GERSHENZON, J. Constitutive emission of the aphid alarm pheromone, $(E)$-b-farnesene, from plants does not serve as a direct defense against aphids. BMC Ecology, v.10, p.1-12, 2010. DOI: 10.1186/1472-6785-10-23.

LAUMANN, R.A.; AQUINO, M.F.S.; MORAES, M.C.B.; PAREJA, M.; BORGES, M. Response of the egg parasitoids Trissolcus basalis and Telenomus podisi to compounds from defensive secretions of stink bugs. Journal of Chemical Ecology, v.35, p.8-19, 2009. DOI: 10.1007/s10886-008-9578-0.

LAUMANN, R.A.; COKL, A.; LOPES, A.P.S; FERREIRA, J.B.C.; MORAES, M.C.B.; BORGES, M. Silent singers are not safe: selective response of a parasitoid to substrate-borne vibratory signals of stink bugs. Animal Behavior, v.82, p.1175-1183, 2011. DOI: 10.1016/j.anbehav.2011.08.017.

LIN, C.; SHEN, B.; XU, Z.; KÖLLNER, T.G.; DEGENHARDT, J.; DOONER, H.K. Characterization of the monoterpene synthase gene tps26, the ortholog of a gene induced by insect herbivory in maize. Plant Physiology, v.146, p.940-951, 2008. DOI: 10.1104/ pp.107.109553.

LOU, Y.G.; MA, B.; CHENG, J.A. Attraction of the parasitoid Anagrus nilaparvatae to rice volatiles induced by the rice brown planthopper Nilaparvata lugens. Journal of Chemical Ecology, v.31, p.2357-2372, 2005. DOI: 10.1007/s10886-005-7106-Z.

MELO MACHADO, R.C.; SANT'ANA, J.; BLASSIOLI-MORAES, M.C.; LAUMANN, R.A.; BORGES, M. Herbivory-induced plant volatiles from Oryza sativa and their influence on chemotaxis behaviour of Tibraca limbativentris stal. (Hemiptera: Pentatomidae) and egg parasitoids. Bulletin of Entomological Research, v.104, p.347-356, 2014. DOI: 10.1017/ s0007485314000133.

MICHEREFF, M.F.F.; BORGES, M.; LAUMANN, R.A.; DINIZ, I.R.; BLASSIOLI-MORAES, M.C. Influence of volatile compounds from herbivore-damaged soybean plants on searching behavior of the egg parasitoid Telenomus podisi. Entomologia Experimentalis et Applicata, v.147, p.9-17, 2013. DOI: 10.1111/ eea.12043.

MICHEREFF, M.F.F.; LAUMANN, R.A.; BORGES, M.; MICHEREFF-FILHO, M.; DINIZ, I.R.; FARIAS NETO, A.L.; MORAES, M.C.B. Volatiles mediating a plant-herbivore-natural enemy interaction in resistant and susceptible soybean cultivars. Journal of Chemical Ecology, v.37, p.273-285, 2011. DOI: 10.1007/s10886-011-9917-4.

MICHEREFF, M.F.F.; MICHEREFF FILHO, M.; BLASSIOLIMORAES, M.C.; LAUMANN, R.A.; DINIZ, I.R.; BORGES, M. Effect of resistant and susceptible soybean cultivars on the attraction of egg parasitoids under field conditions. Journal of Applied Entomology, v.139, p.207-216, 2015. DOI: 10.1111/jen.12148.

MORAES, M.C.B.; LAUMANN, R.A.; PAREJA, M.; SERENO, F.P.S.; MICHEREFF, M.F.F.; BIRKETT, M.A.; PICKETT, J.A.; BORGES, M. Attraction of the stink bug egg parasitoid Telenomus podisi to defence signals from soybean activated by treatment with cis-jasmone. Entomologia Experimentalis et Applicata, v.131, p.178-188, 2009. DOI: 10.1111/j.1570-7458.2009.00836.x.

MORAES, M.C.B.; LAUMANN, R.; SUJII, E.R.; PIRES, C.; BORGES, M. Induced volatiles in soybean and pigeon pea plants artificially infested with the neotropical brown stink bug, Euschistus heros, and their effect on the egg parasitoid, Telenomus podisi. Entomologia Experimetalis et Applicata, v.115, p.227-237, 2005. DOI: 10.1111/j.1570-7458.2005.00290.x.

MORAES, M.C.B.; PAREJA, M.; LAUMANN, R.A.; HOFFMANN-CAMPO, C.B.; BORGES, M. Response of the parasitoid Telenomus podisi to induced volatiles from 
soybean damaged by stink bug herbivory and oviposition. Journal of Plant Interactions, v.3, p.111-118, 2008. DOI: 10.1080/17429140701810724.

PACHECO, D.J.P.; CORRÊA-FERREIRA, B.S. Parasitismo de Telenomus podisi Ashmead (Hymenoptera: Scelionidae) em populações de percevejos pragas da soja. Anais da Sociedade Entomológica do Brasil, v.29, p.295-302, 2000. DOI: 10.1590/ S0301-80592000000200011.

PEMBERTON, R.W.; VANDENBERG, N.J. Extrafloral nectar feeding by ladybird beetles (Coleoptera: Coccinellidae). Proceedings of the Entomological Society of Washington, v.95, p.139-151, 1993.

PEÑAFLOR, M.F.G.V.; ERB, M.; MIRANDA, L.A.; WERNEBURG, A.G.; BENTO, J.M.S. Herbivore-induced plant volatiles can serve as host location cues for a generalist and a specialist egg parasitoid. Journal of Chemical Ecology, v.37, p.1304-1313, 2011. DOI: 10.1007/s10886-011-0047-9.

PICKETT, A.D. Utilization of native parasites and predators. Journal of Economic Entomology, v.52, p.1103-1105, 1959. DOI: 10.1093/jee/52.6.1103.

PRICE, P.W. Insect ecology. $3^{\text {rd }}$ ed. New York: J. Wiley, 1997, 868p.

RASMANN, S.; TURLINGS, T.C.J. First insights into specificity of belowground tritrophic interactions. Oikos, v.117, p.362-369, 2008. DOI: 10.1111/j.2007.0030-1299.16204.x.

SALERNO, G.; FRATI, F.; CONTI, E.; DE PASQUALE, C.; PERI, E.; COLAZZA, S. A finely tuned strategy adopted by an egg parasitoid to exploit chemical traces from host adults. Journal of Experimental Biology, v.212, p.1825-1831, 2009. DOI: 10.1242/ jeb.028308.

SCHNEE, C.; KÖLLNER, T.G.; HELD, M.; TURLINGS, T.C.J.; GERSHENZON, J.; DEGENHARDT, J. The products of a single maize sesquiterpene synthase form a volatile defense signal that attracts natural enemies of maize herbivores. Proceedings of the National Academy of Sciences of the United States of America, v.103, p.1129-1134, 2006. DOI: 10.1073/pnas.0508027103.

SCHOONHOVEN, L.M.; LOON, J.J.A. van; DICKE, M. Insect and plants: how to apply our knowledge. In: SCHOONHOVEN, L.M.; LOON, J.J.A. van; DICKE, M. Insect-plant biology. $2^{\text {nd }}$ ed. Oxford: Oxford University Press, 2005. p.336-363.

SILVA, C.C.; MORAES, M.C.B.; LAUMANN, R.A.; BORGES, M. Sensory response of the egg parasitoid Telenomuspodisi to stimuli from the bug Euschistus heros. Pesquisa Agropecuária Brasileira, v.41, p.1093-1098, 2006. DOI: 10.1590/S0100-204X2006000700004.

SIMPSON, M.; GURR, G.M.; SIMMONS, A.T.; WRATTEN, S.D.; JAMES, D.G.; LEESON, G.; NICOL, H.I.; ORRE, G.U.S. Field evaluation of the 'attract and reward' biological control approach in vineyards. Annals of Applied Biology, v.159, p.69-78, 2011. DOI: 10.1111/j.1744-7348.2011.00477.x.

SUJII, E.R.; COSTA, M.L.M.; PIRES, C.S.S.; COLAZZA, S.; BORGES, M. Inter and intra-guild interactions in egg parasitoid species of the soybean stink bug complex. Pesquisa
Agropecuária Brasileira, v.37, p.1541-1549, 2002. DOI: 10.1590/ S0100-204X2002001100004.

TAKABAYASHI, J.; TAKAHASHI, S.; DICKE, M.; POSTHUMUS, M.A. Developmental stage of herbivore Pseudaletia separata affects production of herbivore-induced synomone by corn plants. Journal of Chemical Ecology, v.21, p.273-287, 1995. DOI: 10.1007/BF02036717.

TOGNON, R.; SANT'ANA, J.; JAHNKE, S.M. Aprendizagem e memória de Telenomus podisi (Hymenoptera, Platygastridae). Iheringia. Série Zoologia, v.103, p.266-271, 2013. DOI: 10.1590/ S0073-47212013000300009.

TOGNON, R.; SANT'ANA, J.; JAHNKE, S.M. Influence of original host on chemotaxic behaviour and parasitism in Telenomus podisi Ashmead (Hymenoptera: Platygastridae). Bulletin of Entomological Research, v.104, p.781-787, 2014. DOI: 10.1017/ S0007485314000649.

TURLINGS, T.C.J.; LOUGHRIN, J.H.; MCCALL， P.J.; RÖSE, U.S.R.; LEWIS, W.J.; TUMLINSON, J.H. How caterpillar-damaged plants protect themselves by attracting parasitic wasps. Proceedings of the National Academy of Sciences of the United States of America, v.92, p.4169-4174, 1995. DOI: 10.1073/pnas.92.10.4169.

TURLINGS, T.C.J.; TUMLINSON, J.H. Do parasitoids use herbivore-induced plant chemical defenses to locate hosts? Florida Entomologist, v.74, p.42-50, 1991. DOI: 10.2307/3495238.

TURLINGS, T.C.J.; WÄCKERS, F. Recruitment of predators and parasitoids by herbivore-injured plants. In: CARDÉ, R.T.; MILLAR, J.G. (Ed.). Advances in insect chemical ecology. Cambridge: Cambridge University Press, 2004. p.21-75. DOI: 10.1017/CBO9780511542664.003.

VET, L.E.M.; DICKE, M. Ecology of infochemical use by natural enemies in a tritrophic context. Annual Review of Entomology, v.37, p.141-172, 1992. DOI: 10.1146/annurev. en.37.010192.001041.

VIEIRA, C.R.; BLASSIOLI-MORAES, M.C; BORGES, M.; PIRES, C.S.S.; SUJII, E.R; LAUMANN, R.A. Field evaluation of $(E)$-2-hexenal efficacy for behavioral manipulation of egg parasitoids in soybean. BioControl, v.59, p.525-537, 2014. DOI: 10.1007/s10526-014-9592-9.

VIEIRA, C.R.; MORAES, M.C.B.; BORGES, M.; SUJII, E.R.; LAUMANN, R.A. cis-Jasmone indirect action on egg parasitoids (Hymenoptera: Scelionidae) and its application in biological control of soybean stink bugs (Hemiptera: Pentatomidae). Biological Control, v.64, p.75-82, 2013. DOI: 10.1016/j. biocontrol.2012.10.004

VINSON, S.B. The behaviour of parasitoids. In: KERKUT, G.A.; GILBERT,L.I.(Eds.). Comprehensiveinsectphysiology, biochemistry and pharmacology. Oxford: Pergamon, 1985. p.417-469.

WAR, A.R.; PAULRAJ, M.G.; AHMAD, T.; BUHROO, A.A.; HUSSAIN, B.; IGNACIMUTHU, S.; SHARMA, H.C. Mechanisms of plant defense against insect herbivores. Plant Signaling and Behavior, v.7, p.1306-1320, 2012. DOI: 10.4161/psb.21663.

Received on June 25, 2015 and accepted on December 10, 2015

Pesq. agropec. bras., Brasília, v.51, n.5, p.454-464, maio 2016

DOI: 10.1590/S0100-204X2016000500005 